\title{
Analisis Kelayakan Finansial Perencanaan Ruang Parkir di Jalan Jawa Kabupaten Jember
}

\author{
Ahmad Fikri', Akhmad Hasanudin ${ }^{1}$, Willy Kriswardhana*1 \\ ${ }^{1}$ Jurusan Teknik Sipil, Fakultas Teknik, Universitas Jember \\ E-mail: *willy.teknik@unej.ac.id
}

Received 30 July 2020; Reviewed 14 October 2020; Accepted 15 February 2021

Journal Homepage: http://jurnal.borneo.ac.id/index.php/borneoengineering

\begin{abstract}
One of the streets with extremely high activities in Jember City is Jawa Street. Even though it has a wide enough track, it is common to find a long queue of vehicles in this area. It is because the available typical parking facility on this street is on-street parking. This study aims to plan a parking space on Jawa Street to reduce vehicles that parked on the streat and analyze the financial feasibility of the parking lot. The results of this planning revealed that the parking volume of twowheeled vehicles was 1.472 vehicles with 439 parking areas needed. For four-wheeled vehicles, the volume was 221 vehicles with 84 parking areas needed. The planned parking area is 650 vehicles for two wheels For financial analysis, the NPV values reached $0.37 \%-0,56 \%$ with an IRR value of $0,55 \%$ and a BCR value of 1,55. Based on these results, the investment in parking planning is considered feasible. For the next payback period, it can use a graph to get the BEP in the 8th month.
\end{abstract}

Keywords: On Street Parking, Parking Volume, Parkir Capasity, Parking Index, Financial Analysis

\begin{abstract}
Abstrak
Jalan Jawa merupakan salah satu jalan yang memiliki aktivitas sanggat tinggi di kota Jember. Meskipun memiliki lebar jalur yang cukup lebar, namun masih sering terjadi antrian kendaraan yang cukup panjang. Hal ini disebabkan fasilitas parkir yang tersedia di Jalan Jawa sebagian besar hanya ada di badan jalan (On Street Parking). Penelitian ini bertujuan untuk merencanakan lahan parkir pada Jalan Jawa Jember untuk mengurangi kendaraan yang terparkir pada badan jalan dan menganalisis kelayakan finansial lahan parkir tersebut. Hasil survei menunjukkan volume parkir kendaraan roda dua sebesar 1.472 kendaraan dengan kebutuhan petak parkir sebesar 439 kendaraan. Untuk roda empat volumenya sebesar 221 kendaraan dengan kebutuhan petak parkir sebesar 84 kendaraan. Lahan parkir direncanakan untuk kendaraan roda dua dengan kapasitas petak parkir sebesar 650 kendaraan. Berdasarkan hasil analisis finansial, didapatkan nilai nilai sebagai berikut, NPV sebesar 0,37\% - 0,56\%, IRR sebesar 0,55\%, BCR sebesar 1,55, dan Payback Period pada bulan ke-8.
\end{abstract}

Kata kunci: On Street Parking, Volume Parkir, Kapasitas Parkir, Indeks Parkir, Analisis Finansial

\section{Pendahuluan}

Salah satu jalan yang memiliki aktivitas sangat tinggi di kota Jember adalah Jalan Jawa. Selain masih merupakan area Universitas Jember, Jalan Jawa juga merupakan pusat berbagai macam 
pertokoan, lembaga pemerintahan, dan lembaga pendidikan. Jalan Jawa merupakan jalan dengan lebar jalur bervariasi mulai $8 \mathrm{~m}, 12 \mathrm{~m}$, dan $12,5 \mathrm{~m}$. Meskipun memiliki lebar jalur yang cukup lebar, namun masih sering terjadi antrian kendaraan yang cukup panjang. Hal ini disebabkan fasilitas parkir yang tersedia di Jalan Jawa sebagian besar hanya ada di badan jalan (On Street Parking).

Tingginya volume lalu lintas di Jalan Jawa dapat dibuktikan oleh hasil survei lalu lintas yang telah dilakukan mahasiswa Teknik Sipil tahun 2018. Dari data hasil survei didapatkan rata rata total arus kendaraan yaitu 1.421 satuan mobil penumpang (smp)/jam. Namun angka tersebut tidak menunjukkan bahwa volume arus lalu lintas menjadi penyebab kemacetan yang terjadi di Jalan Jawa. Menurut Manual Kapasitas Jalan Indonesia 1997 (MKJI, 1997), kapasistas dasar kendaraan untuk tipe jalan 2 lajur 2 arah tak terbagi adalah 2.900 satuan mobil penumpang (smp)/jam.

Faktor yang menyebabkan adanya antrian kendaraan yang cukup panjang dan mempengaruhi kecepatan kendaraan adalah hambatan samping. Hal ini dapat dibuktikan dengan hasil survei yang sama, menunjukkan bahwa naiknya angka frekuensi berbobot hambatan samping diikuti dengan turunnya angka kecepatan kendaraan. Dalam beberapa penelitian sebelumnya juga menunjukkan adanya hubungan hambatan samping dengan kinerja ruas jalan. Penilitian yang dilakukan pada ruas Jalan Lumimut Kota Medan didapatkan pengaruh kendaraan parkir dan berhenti sebesar 62,65\% terhadap menurunnya kecepatan kendaraan yang melintas (Rauf H. dkk., 2015). Faktor hambatan samping mempengaruhi kecepatan kendaraan sebesar 83,08\% pada ruas jalan Jalan Sarapung Kota Medan. (Tataming dkk., 2014). Survei yang dilaksanakan pada Jalan Jawa Jember didapatkan pengaruh hambatan samping sebesar 97\% terhadap kapasitas ruas jalan dengan variabel tertinggi pada pejalan kaki, kendaraan parkir berhenti, dan kendaraan keluar masuk. (Kriswardhana dan Wahyudi, 2017). Dapat disimpulkan besarnya hambatan samping mempengaruhi perubahan kecepatan kendaraan sehingga menyebabkan arus lalu lintas pada Jalan Jawa menjadi arus terganggu. Selama ini, penelitian di bidang transportasi seringkali hanya berfokus pada penataan parkir, tanpa memperhitungkan akibat finansial yang ditimbulkan oleh adanya rekayasa lalu lintas. Oleh karena itu, penelitian ini bertujuan untuk merencanakan fasilitas parkir yang tepat untuk mengurangi panjangnya antrian kendaraan pada ruas Jalan Jawa Jember yang disebabkan oleh on street parking dan memperkirakan kelayakannya dari sisi finansial.

\section{Metode Penelitian}

\subsection{Lokasi Lahan Parkir}

Lokasi lahan parkir yang direncanakan terletak pada Jalan Jawa Jember seperti tertera pada Gambar 1 berikut ini,

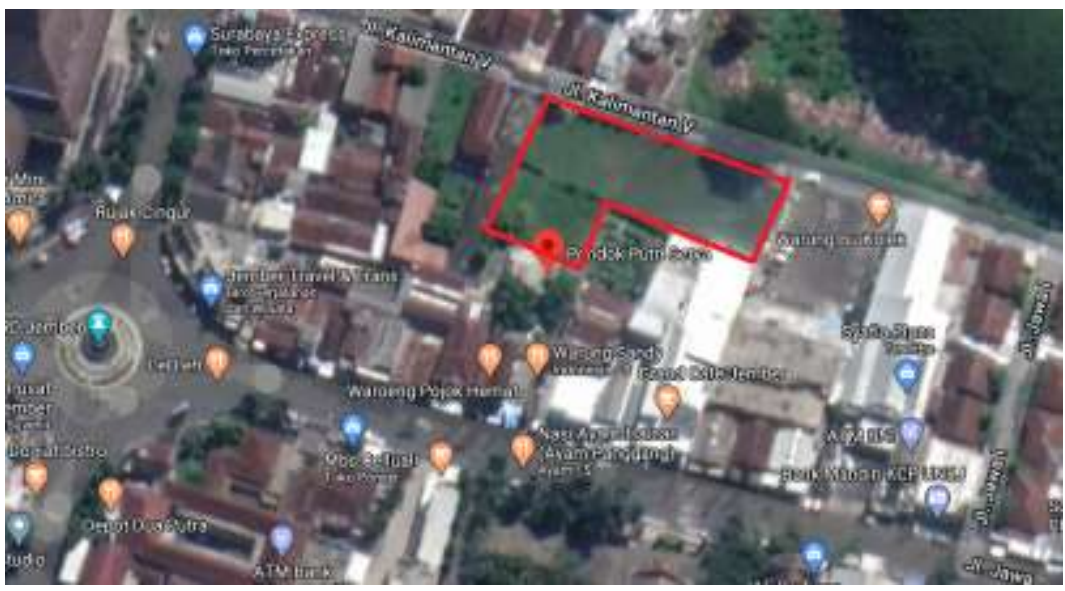

Gambar 1. Lokasi Lahan Parkir 


\subsection{Survei Volume Parkir}

Survei volume kendaraan parkir pada badan jalan (On Street Parking) dilakukan pada Jalan Jawa sepanjang 300m seperti pada Gambar 2 berikut,

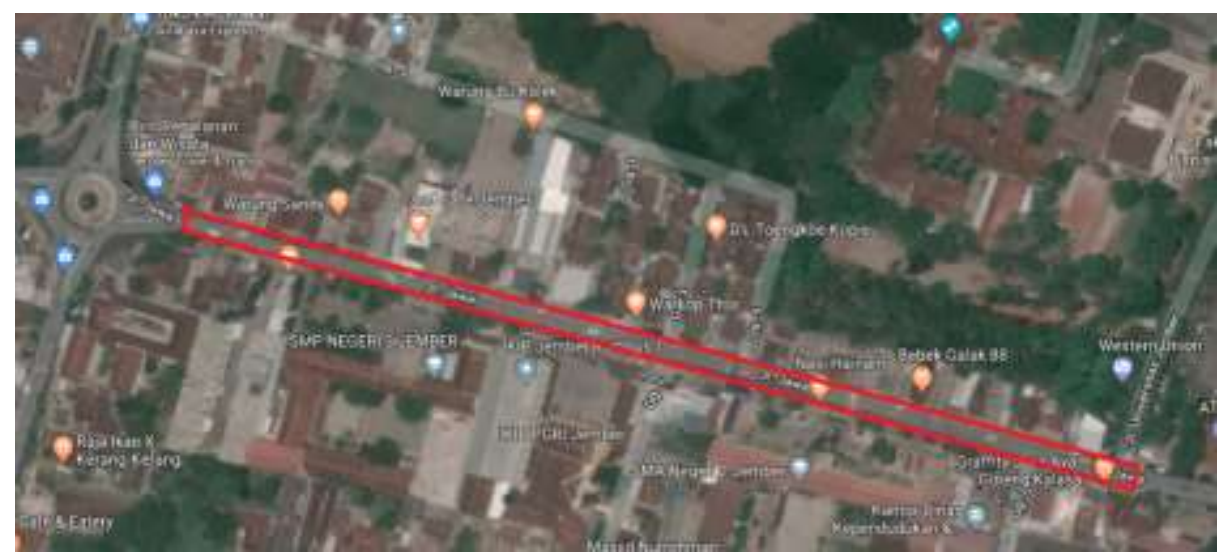

Gambar 2. Lokasi Survei Volume Parkir

Survei dilaksanakan dua hari yaitu Hari Senin untuk mewakili weekday, tepatnya pada 17 Februari 2020, dan Hari Sabtu untuk mewakili weekend, tepatnya pada 15 Februari 2020 pada pukul 09.00 21.00 WIB. Waktu yang digunakan berdasarkan jam operasional pertokoan yang terdapat pada Jalan Jawa Jember. Volume kendaraan parkir pada badan jalan digunakan untuk mencari indeks parkir sehingga didapatkan kebutuhan petak parkir untuk masing masing jenis kendaraan.

\subsection{Kapasitas Lahan Parkir}

Untuk mencari kapasitas petak parkir pada lahan parkir yang direncanakan, digunakan cara cobacoba menggunakan software AutoCad dengan asumsi lahan parkir direncanakan untuk satu jenis kendaraan.

\subsection{Analisis Finansial}

Tahapan analisis finansial dimulai dengan merancang Rencana Anggaran Biaya (RAB) proyek lahan parkir tersebut beserta biaya operasional perbulannya. Pendapatan lahan parkir berasal dari retribusi kendaraan parkir yang telah ditetapkan.Setelah mendapatkan angka pendapatan dan pengeluaran, maka dapat ditentukan nilai Net Present Value (NPV), Internal Rate of Return (IRR), Benefit Cost Ratio (BCR), dan Payback Periodnya. Suku bunga yang digunakan diambil berdasarkan suku bunga acuan tetap Bank Indonesia per Maret 2020 sebesar 4,5\%.

\subsubsection{Net Present Value (NPV)}

NPV dapat diartikan sebagai selisih dari Present Value komponen manfaat dengan Present Value komponen biaya. Jika nilai NPV lebih dari 0 maka investasi dinyatakan layak. Untuk mencari nlai NPV, digunakan Persamaan sebagai berikut,

$$
N P V=\sum_{t=1}^{T} \frac{C_{t}}{(1+r)^{t}}-C_{o}
$$

Dimana :

$\mathrm{C}(\mathrm{t})=$ Arus kas per tahun

$\mathrm{C}(\mathrm{o})=$ Nilai investasi pada awal tahun ke 0

$\mathrm{r} \quad=$ Tingkat bunga 


\subsubsection{Internal Rate Of Return (IRR)}

IRR adalah nilai discount rate pada saat nilai NPV sama dengan 0. Jika nilai IRR melebihi suku bunga yang dipakai, maka investasi dinyatakan layak. Untuk mencari nilai IRR, digunakan persamaan 2 sebagai berikut,

$$
I R R=I r+\frac{N P V}{N P V I r-N P V I t}(I t-I r)
$$

Dimana:

Ir = Bunga rendah

It = Bunga tinggi

NPVIr $=$ NPV bunga rendah

NPVIt $=$ NPV bunga tinggi

\subsubsection{Benefit Cost Ratio (BCR)}

BCR mencari tingkat keefektifan penggunan komponen biaya terhadap komponen manfaat. Jika nilai BCR melebihi 1 maka investasi dinyatakan layak. Untuk mencari nilai BCR, digunakan persamaan sebagai berikut.

$$
B C R=\frac{\text { Total Pendapatan Per Tahun }}{\text { Total Pengeluaran Tahun ke } 0}
$$

\subsubsection{Payback Period}

Payback Period adalah waktu yang diperlukan agar modal investasi yang ditanamkan dapat kembali dengan menghitung aliran kas bersih. Jika waktu pengembalian modal lebih pendek dari usia proyek maka investasi tersebut dinyatakan layak.

\section{Hasil dan Pembahasan}

\subsection{Survei Volume Kendaraan Parkir}

Hasil survei volume kendaraan parkir untuk kendaraan roda dua dan roda empat adalah sebagai berikut

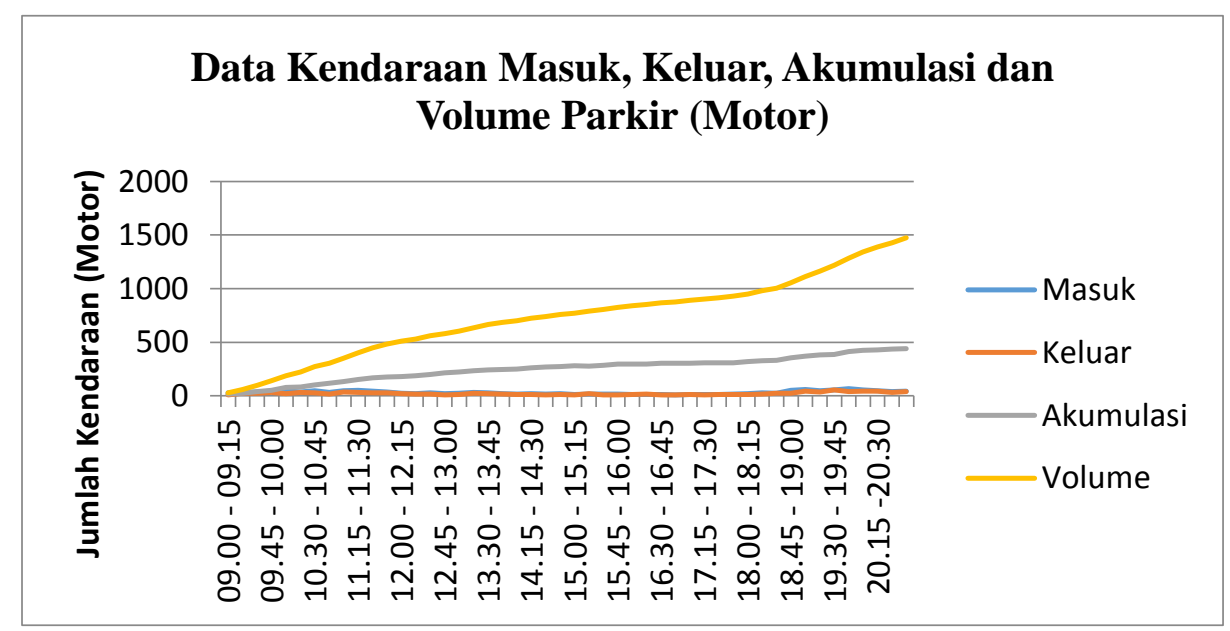

Gambar 3. Grafik Volume Kendaraan Roda Dua Senin

Berdasarkan Gambar 3 tersebut, diperoleh angka total volume kendaraan parkir roda dua Hari Senin sebesar 1.472 kendaraan dengan akumulasi maksimal sebesar 439 kendaraan. 


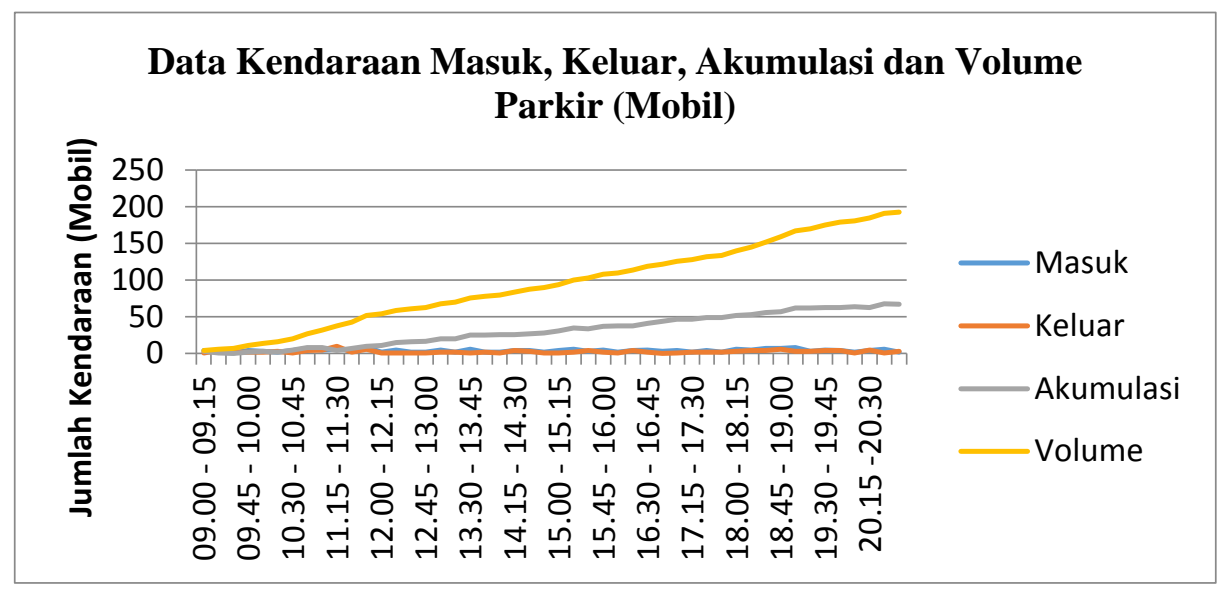

Gambar 4. Grafik Volume Kendaraan Roda Empat Senin

Berdasarkan Gambar 4 tersebut, diperoleh angka total volume kendaraan parkir roda empat Hari Senin sebesar 193 kendaraan dengan akumulasi maksimal sebesar 68 kendaraan.

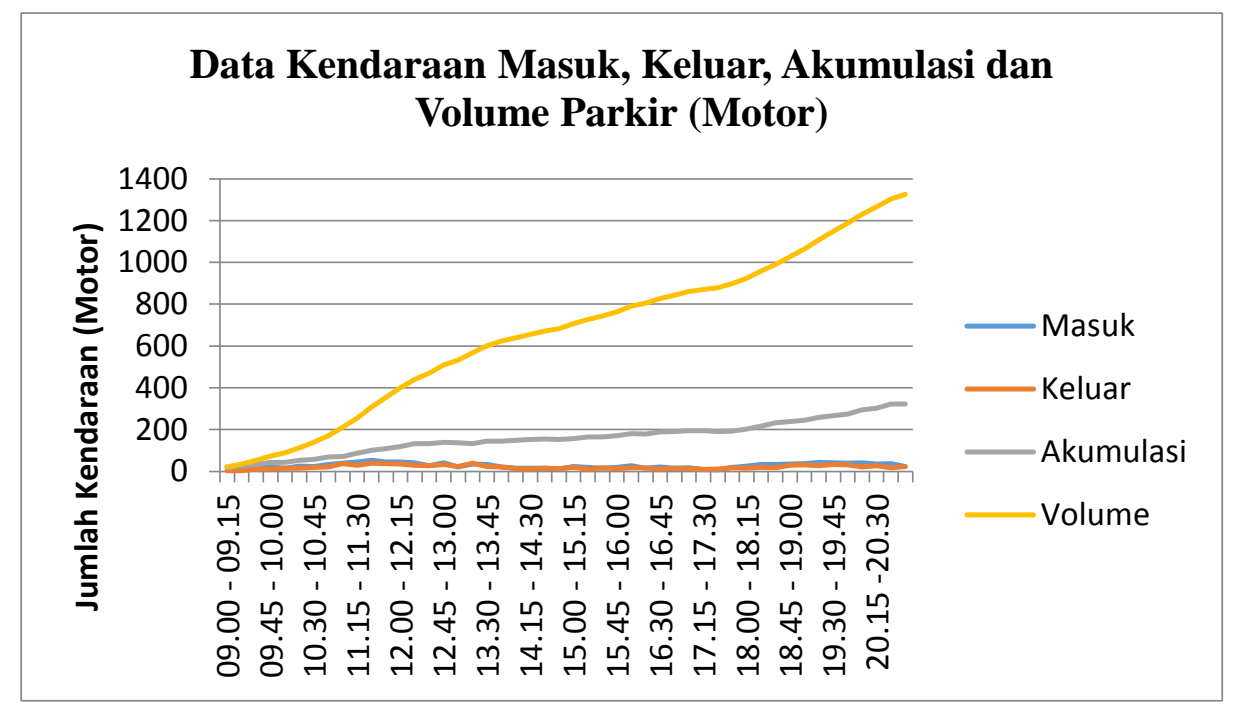

Gambar 5. Grafik Volume Kendaraan Roda Dua Sabtu

Berdasarkan Gambar 5, didapatkan angka total volume kendaraan parkir roda dua Hari Sabtu sebesar 1.326 kendaraan dengan akumulasi maksimal sebesar 323 kendaraan.

Berdasarkan Gambar 6 di bawah ini, diperoleh angka total volume kendaraan parkir roda empat Hari Sabtu sebesar 221 kendaraan dengan akumulasi maksimal sebesar 84 kendaraan.

Dari hasil tersebut, maka digunakan volume maksimal untuk kendaraan roda dua pada Hari Senin sebesar 1.472 kendaraan dengan akumulasi maksimal sebesar 439 kendaraan. Untuk roda empat pada Hari Sabtu sebesar 221 kendaraan dengan akumulasi maksimal sebesar 84 kendaraan. 


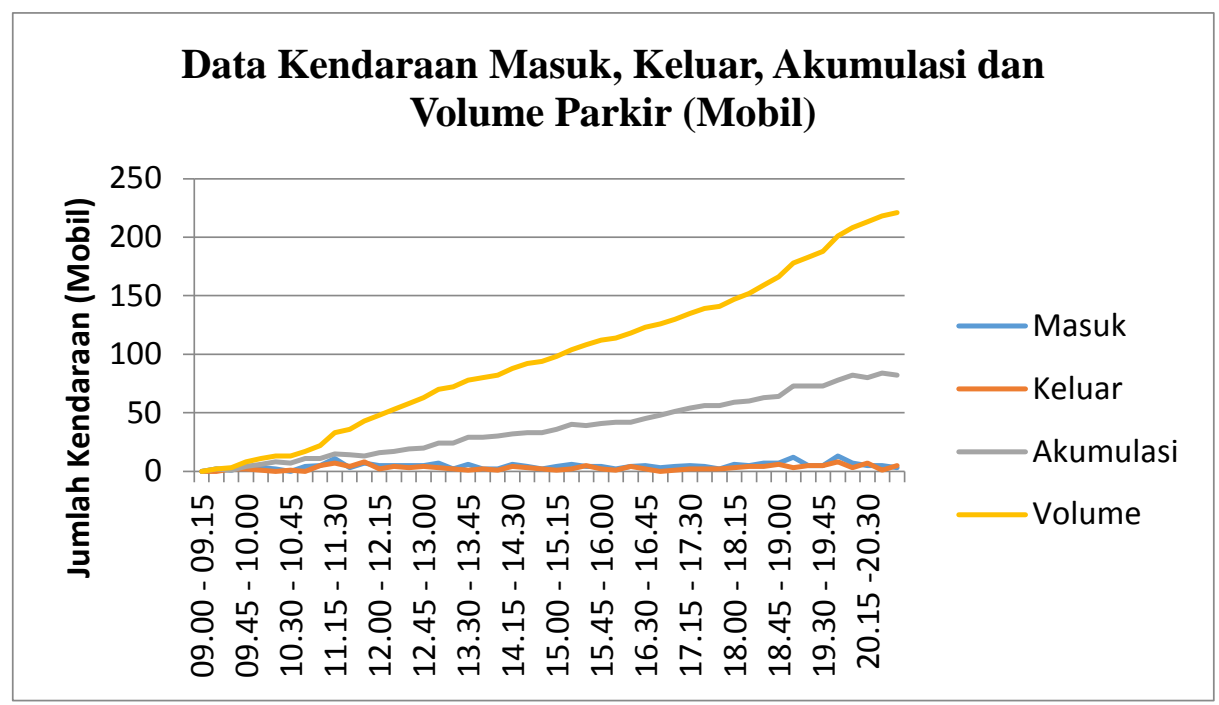

Gambar 6. Grafik Volume Kendaraan Roda Empat Sabtu

\subsection{Kapasitas Parkir}

Dengan mengetahui luas lahan sebesar $1800 \mathrm{~m}^{2}$, maka dapat diketahui luas area sirkulasi kendaraan dan jumlah petak parkir berdasarkan Satuan Ruang Parkir (SRP) masing-masing jenis kendaraan. Satuan Ruang Parkir yang digunakan berdasarkan Pedoman Perencanaan dan Pengoperasian Fasilitas Parkir Dirjen Perhubungan Darat Tahun 1998.

\subsubsection{Kapasitas Parkir Kendaraan Roda Dua}

Tabel 1. Kapasitas Parkir Kendaraan Roda Dua

\begin{tabular}{cccccc}
\hline $\begin{array}{c}\text { Sudut } \\
\text { Parkir }\end{array}$ & \multicolumn{2}{c}{ Luasan Petak $(\mathbf{m})$} & $\begin{array}{c}\text { Luas Gang } \\
\left(\mathbf{m}^{\mathbf{2}}\right)\end{array}$ & $\begin{array}{c}\text { Luas Lahan } \\
\text { Parkir }\left(\mathbf{m}^{\mathbf{2}}\right)\end{array}$ & $\begin{array}{c}\text { Jumlah Petak } \\
\text { Parkir }\end{array}$ \\
\cline { 2 - 3 } $90^{0} 1$ Arah & 0,75 & 2,0 & 825,50 & $1.800,00$ & 650 \\
\hline
\end{tabular}

Berdasarkan Tabel 1, dapat diketahui kapasitas parkir kendaraan roda dua pada lahan seluas 1800 $\mathrm{m}^{2}$ adalah sebesar 650 petak parkir.

\subsubsection{Kapasitas Parkir Kendaraan Roda Empat}

Tabel 2. Kapasitas Parkir Kendaraan Roda Empat

\begin{tabular}{cccccc}
\hline Sudut Parkir & \multicolumn{2}{c}{ Luas an Petak $(\mathbf{m})$} & Luas Gang & Luas Lahan & $\begin{array}{c}\text { Jumlah Petak } \\
\text { Parkir }\end{array}$ \\
\hline $30^{0} 1$ Arah & 2,5 & 5 & 1072,56 & 1800 & 34 \\
\hline $45^{0} 1$ Arah & 2,5 & 5 & 982,12 & 1800 & 42 \\
\hline $60^{0} 1$ Arah & 2,5 & 5 & 1002,35 & 1800 & 41 \\
\hline $90^{\circ} 1$ Arah & 2,5 & 5 & 1228,75 & 1800 & 46 \\
\hline
\end{tabular}




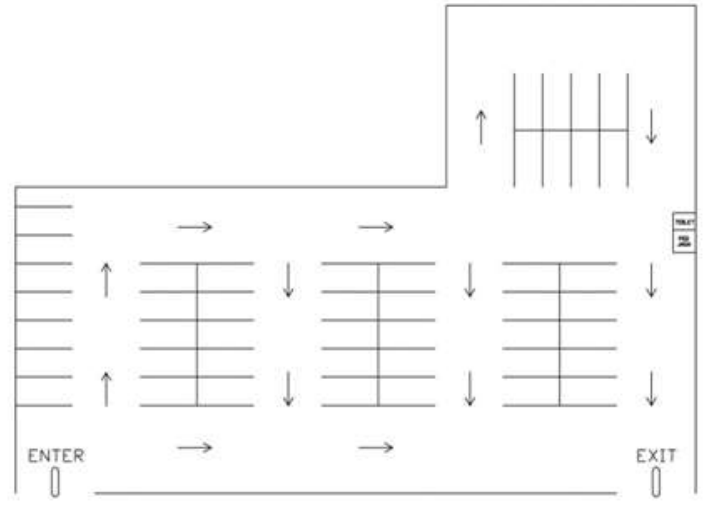

Gambar 7. Parkir Mobil Sudut $90^{\circ}$

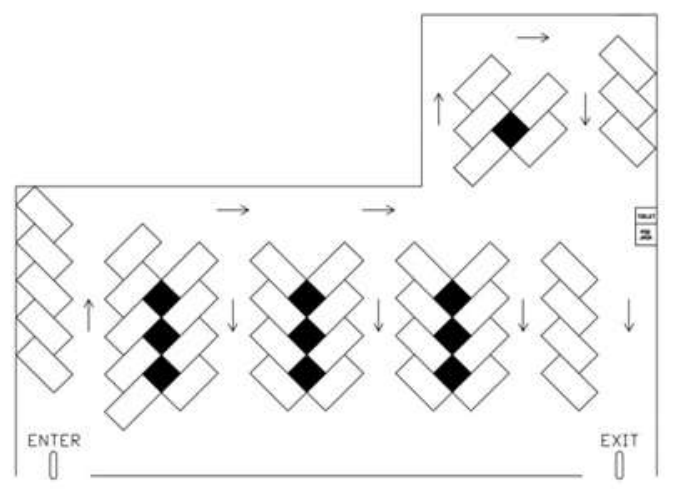

Gambar 9. Parkir Mobil Sudut $45^{\circ}$

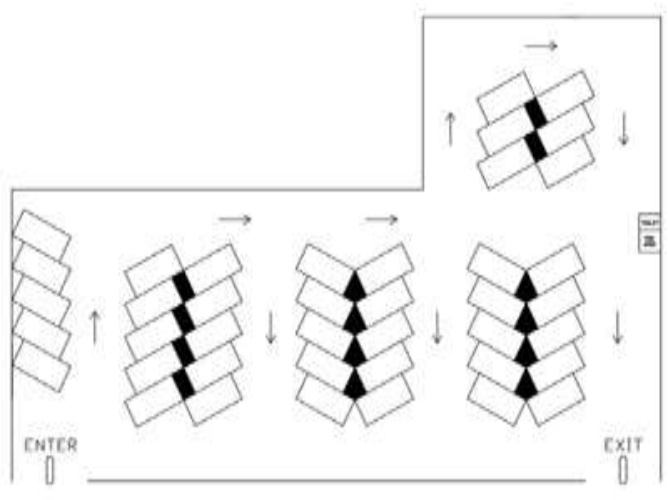

Gambar 8. Parkir Mobil Sudut $60^{\circ}$

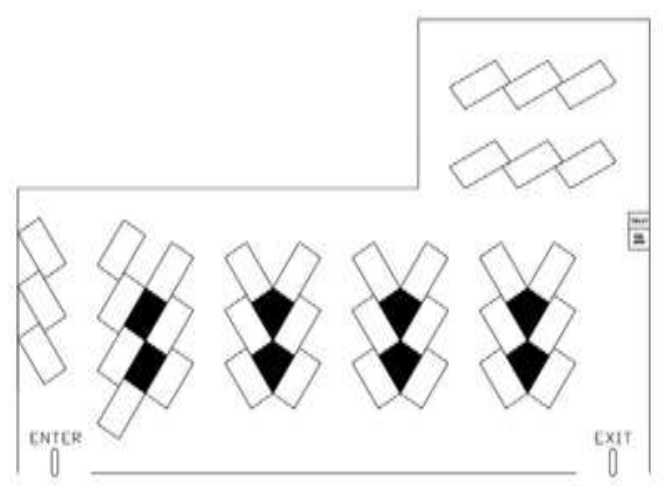

Gambar 10. Parkir Mobil Sudut $30^{\circ}$

Berdasarkan Gambar 7,8,9 dan 1 dapat diketahui kapasitas parkir maksimal kendaraan roda empat pada lahan seluas $1.800 \mathrm{~m}^{2}$ adalah dengan posisi $90^{\circ} 1$ Arah sebesar 46 petak parkir.

\subsection{Indeks Parkir}

Setelah mendapatkan volume maksimal dan akumulasi maksimal dari setiap jenis kendaraan maka dapat ditentukan nilai indeks parkirnya.

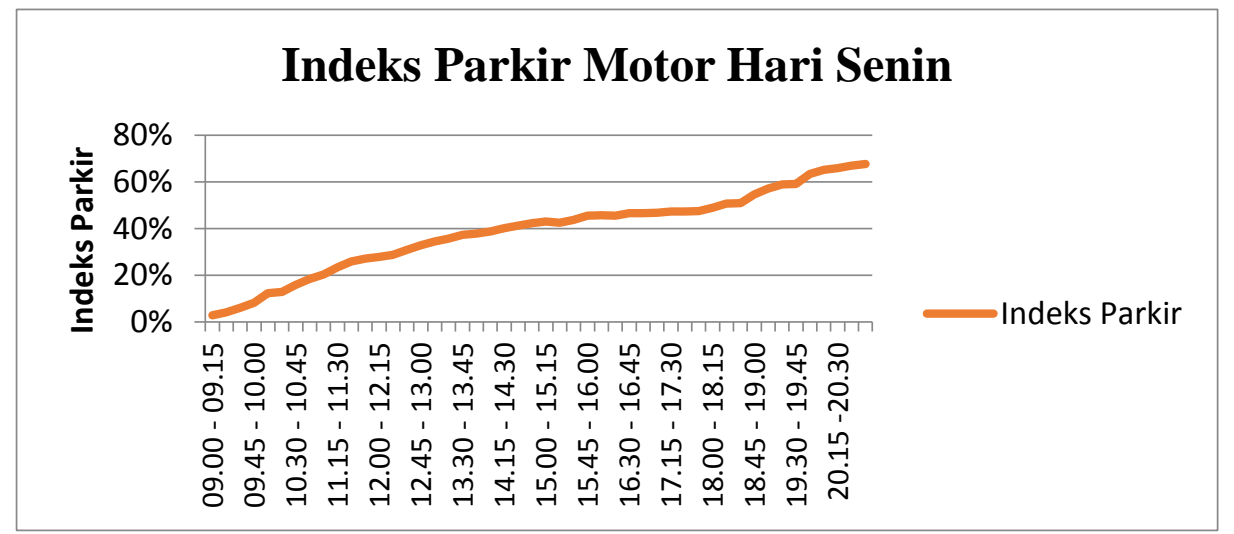

Gambar 11. Indeks Parkir Motor Hari Senin 
Berdasarkan Gambar 11, dapat diketahui nilai indeks parkir Motor Hari Senin maksimal terjadi pada pukul $20.45-21.00$ dengan nilai $67,57 \%$.

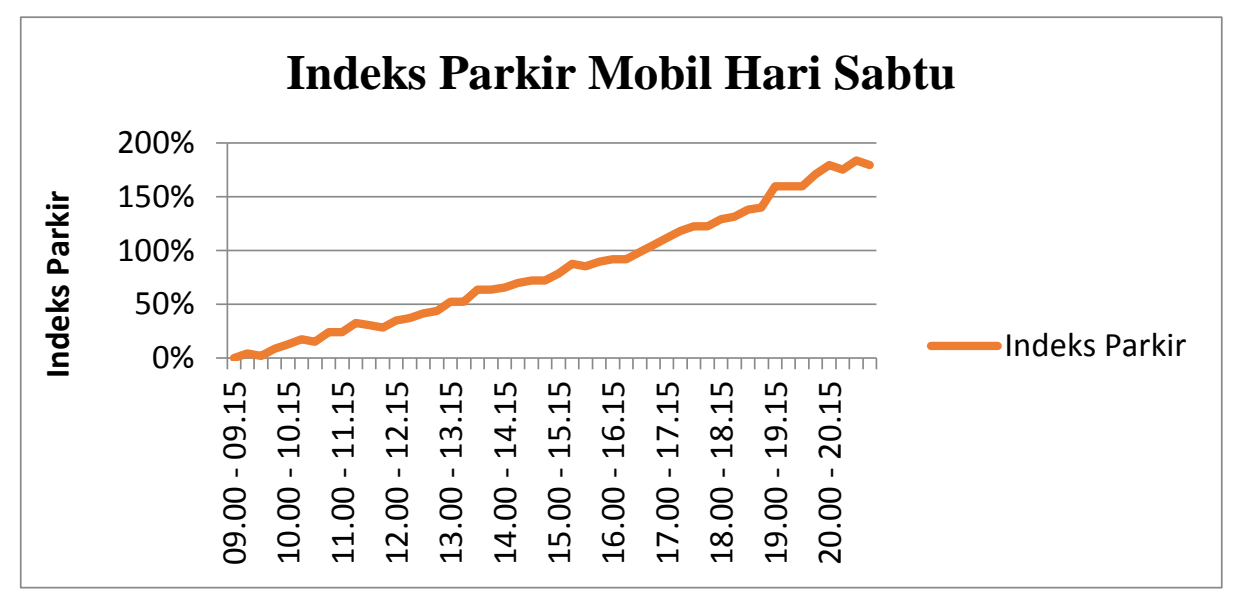

Gambar 12. Indeks Parkir Mobil Hari Sabtu

Berdasarkan Gambar 12 diatas, dapat diketahui nilai Indeks Parkir Mobil maksimal pada Hari Sabtu terjadi pada pukul 20.30 - 20.45 dengan nilai 183,80\%. Nilai indeks parkir dapat melebihi angka $100 \%$ dikarenakan akumulasi parkir kendaraan yang dipakai adalah akumulasi parkir pada badan jalan, sedangkan kapasitas parkir yang digunakan adalah kapasitas parkir pada lahan baru. Nilai indeks parkir eksisting untuk kendaraan roda empat pada hari sabtu adalah 89,09\%.

\subsection{Kebutuhan Petak Parkir}

Dari nilai indeks parkir yang didapatkan, dapat diketahui kebutuhan petak parkir untuk masing masing jenis kendaraan. Hasilnya adalah, untuk kendaraan roda dua membutuhkan 439 petak parkir dengan tidak perlu penambahan petak parkir pada lahan yang ada. Untuk roda empat membutuhkan 84 petak parkir dengan perlu penambahan 38 petak parkir pada lahan yang ada seperti tertera pada Tabel 3 berikut ini.

Tabel 3. Kebutuhan Petak Parkir

\begin{tabular}{lcc}
\hline & Motor & Mobil \\
\hline Indeks parkir (\%) & 67,57 & 183,81 \\
Kebutuhan & 439 & 84 \\
Ketersediaan & 650 & 46 \\
Kekurangan & - & 38 \\
\hline
\end{tabular}

Dengan hasil tersebut,maka lahan parkir diperuntukkan hanya untuk kendaraan roda, sementara itu parkir untuk kendaraan roda empat tetap pada badan jalan (On Street Parking) dengan posisi parkir satu sisi $45^{\circ}$ dikarenakan dapat menampung kebutuhan petak parkir kendaraan roda empat seperti tergambar pada Tabel 4. 
Tabel 4. Kapasitas Petak Parkir Pada Badan Jalan

\begin{tabular}{cccc}
\hline Sudut Parkir & $\begin{array}{c}\text { Panjang } \\
\text { Lahan } \\
\text { Parkir } \\
(\mathbf{m})\end{array}$ & $\begin{array}{c}\text { Lebar } \\
\text { Petak } \\
\text { Parkir }(\mathbf{m})\end{array}$ & $\begin{array}{c}\text { Jumlah petak } \\
\text { Parkir }\end{array}$ \\
\hline Paralel & 330 & 6 & 55 \\
\hline $30^{\circ}$ & 330 & 4,6 & 71,74 \\
$45^{\circ}$ & 330 & 3,5 & 94,29 \\
$60^{\circ}$ & 330 & 2,9 & 113,79 \\
$90^{\circ}$ & 330 & 2,3 & 143,48 \\
\hline
\end{tabular}

\subsection{Analisis Finansial}

\subsubsection{Rencana Anggaran Biaya (RAB)}

Rencana Anggaran Biaya dan Biaya operasional dapat dilihat pada Tabel 5 berikut ini,

Tabel 5. Rekap Rencana Anggaran Biaya

\begin{tabular}{cllr}
\hline NO & \multicolumn{1}{c}{ PEKERJAAN } & \multicolumn{1}{c}{ HARGA } \\
\hline 1 & Pembersihan Lahan & $\mathrm{Rp}$ & 3.553 .520 \\
2 & Pekerjaan Pemasangan Paving Block & $\mathrm{Rp}$ & 117.225 .500 \\
3 & Pekerjaan Finishing & $\mathrm{Rp}$ & 22.501 .597 \\
4 & Pembangunan Pos Jaga & $\mathrm{Rp}$ & 10.739 .714 \\
5 & Pembangunan Toilet & $\mathrm{Rp}$ & 8.083 .174 \\
6 & Pekerjaan Lain-Lain & $\mathrm{Rp}$ & 299.641 .496 \\
7 & Biaya Operasional & $\mathrm{Rp}$ & 11.562 .784 \\
8 & Sewa Lahan Per Tahun & $\mathrm{Rp}$ & 50.000 .000 \\
\hline & TOTAL BIAYA & $\mathrm{Rp}$ & 523.307 .785 \\
\hline
\end{tabular}

Dapat dilihat bahwa total biaya pembangunan lahan parkir beserta biaya operasionalnya sebesar Rp.523.207.785.

\subsubsection{Pendapatan}

Pendapatan lahan parkir didapatkan dari retribusi parkir, dalam hal ini retribusi parkir kendaraan roda dua sebesar Rp. 1500. Dengan total volume 1.472 kendaraan per hari, pendapatan lahan parkir perharinya sebesar Rp. 2.208.000.

Untuk pendapatan pada bulan pertama hingga bulan ke-12 pada tahun pertama, digunakan rumus suku bunga majemuk. Dengan suku bunga acuan sebesar 4,5\% per tahun atau sama dengan 0,37\% per bulan, maka didapatkan pendapatan lahan parkir seperti tabel berikut.

Dari Tabel 6 dapat diketahui pendapatan lahan parkir pada bulan ke-12 pada tahun pertama sebesar Rp811.256.980. 
Tabel 6. Pendapatan Lahan Parkir

\begin{tabular}{cccrlr}
\hline Bulan Ke & \multirow{2}{*}{ Suku Bunga } & \multicolumn{2}{c}{ Pendapatan } & \multicolumn{2}{c}{ Total Pendapatan } \\
\hline 1 & & $\mathrm{Rp}$ & 66.240 .000 & $\mathrm{Rp}$ & 66.240 .000 \\
2 & 0,0074 & $\mathrm{Rp}$ & 66.485 .088 & $\mathrm{Rp}$ & 132.725 .088 \\
3 & 0,0111 & $\mathrm{Rp}$ & 66.731 .083 & $\mathrm{Rp}$ & 199.456 .171 \\
4 & 0,0149 & $\mathrm{Rp}$ & 66.977 .988 & $\mathrm{Rp}$ & 266.434 .159 \\
5 & 0,0186 & $\mathrm{Rp}$ & 67.225 .806 & $\mathrm{Rp}$ & 333.659 .965 \\
6 & 0,0224 & $\mathrm{Rp}$ & 67.474 .542 & $\mathrm{Rp}$ & 401.134 .507 \\
7 & 0,0262 & $\mathrm{Rp}$ & 67.724 .198 & $\mathrm{Rp}$ & 468.858 .705 \\
8 & 0,0300 & $\mathrm{Rp}$ & 67.974 .777 & $\mathrm{Rp}$ & 536.833 .482 \\
9 & 0,0338 & $\mathrm{Rp}$ & 68.226 .284 & $\mathrm{Rp}$ & 605.059 .766 \\
10 & 0,0376 & $\mathrm{Rp}$ & 68.478 .721 & $\mathrm{Rp}$ & 673.538 .487 \\
11 & 0,0415 & $\mathrm{Rp}$ & 68.732 .092 & $\mathrm{Rp}$ & 742.270 .579 \\
12 & 0,0453 & $\mathrm{Rp}$ & 68.986 .401 & $\mathrm{Rp}$ & 811.256 .980 \\
\hline
\end{tabular}

\subsubsection{Net Present Value}

Setelah diketahui total pengeluaran dan pendapatan lahan parkir, dapat diketahui nilai Net Present Value (NPV) menggunakan rumus yang ada sehingga didapatkan hasil sebagai berikut.

Tabel 8. Net Present Value (NPV)

\begin{tabular}{|c|c|c|c|c|c|}
\hline Jenis NPV & $\mathbf{C t}$ & & Co & $\mathbf{r}$ & NPV \\
\hline Positif & $\begin{array}{ll}\mathrm{Rp} & 811.256 .980\end{array}$ & $\mathrm{Rp}$ & 523.307 .785 & 0,37 & Rp 68.850 .595 \\
\hline Negatif & Rp 811.256 .980 & $\mathrm{Rp}$ & 523.307 .785 & 0,56 & $\mathrm{Rp} \quad(3.271 .259)$ \\
\hline
\end{tabular}

Dari tabel tersebut dapat dilihat nilai NPV positif pada suku bunga 0,37\% sebesar Rp 68.850.595. Untuk NPV negatif dengan suku bunga 0,56\% sebesar Rp (3.271.259). Nilai tersebut berarti jika suku bunga masih berada diantara $0,37 \%-0,56 \%$ maka investasi dinyatakan layak.

\subsubsection{Internal Rate of Return}

Setelah mendapatkan nilai NPV positif dan NPV negatif, makan dapat dicari nilai IRR menggunakan persamaan 2, sehinggal didapatkan hasil sebagai berikut.

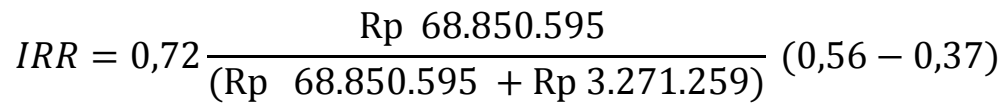

$$
\begin{aligned}
& I R R=0,55 \%
\end{aligned}
$$

Dikarenakan nilai Internal Rate Of Returnnya adalah 0,55\% per bulan atau 6,6\% per tahun atau melebihi tingkat suku bunga, maka investasi tersebut dinyatakan layak.

\subsubsection{Benefit Cost Ratio (BCR)}

Dengan mengetahui pendapatan dan pengeluaran proyek lahan parkir, dapat diketahui nilai BCRnya sebagai berikut. 


$$
\begin{gathered}
B C R=\frac{\operatorname{Rp} 811.256 .980}{\operatorname{Rp} 523.307 .785} \\
B C R=1,55
\end{gathered}
$$

Diketahui nilai BCR nya sebesar 1,55 atau melebihi 1, oleh karena itu investasi dinyatakan layak.

\subsubsection{Payback Period}

Nilai Payback Period dicari menggunakan cara grafik sehingga dapat ditentukan titik Break Event Pointnya (BEP) seperti grafik berikut.

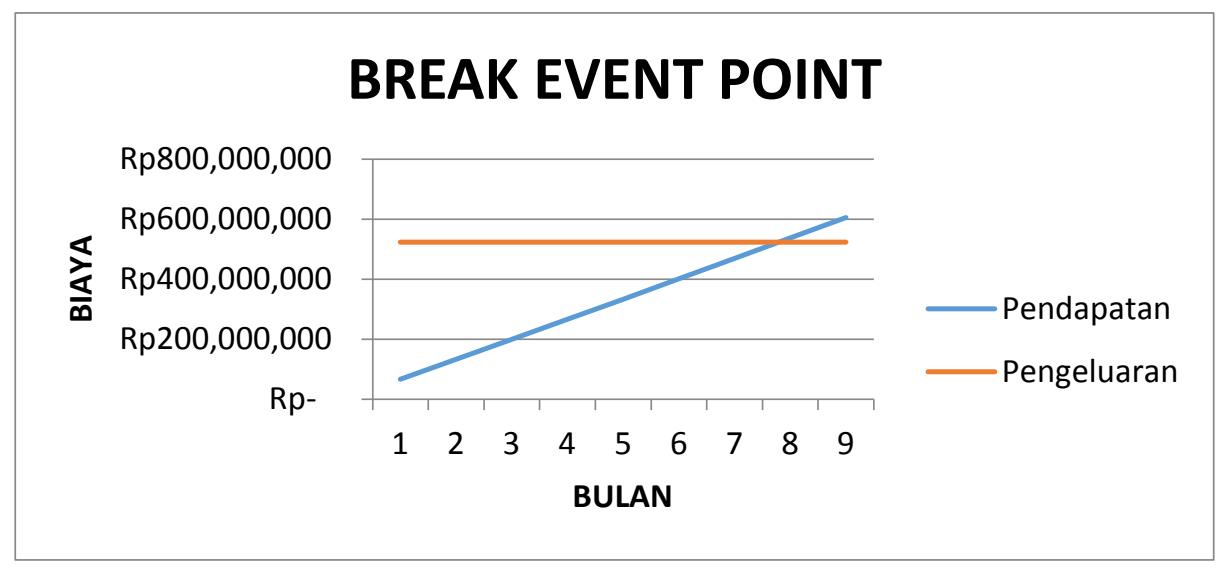

Gambar 13. Grafik Break Event Point

Berdasarkan grafik tersebut, dapat diketahui bahwa payback periodnya jatuh pada bulan ke-8.

Sehingga pada penelitian kali ini didapatkan adanya pengaruh hambatan samping, dalam hal ini adalah kendaraan parkir pada badan jalan terhadap arus lalu lintas di sekitarnya. Oleh sebab itu, direncanakan pembangunan lahan parkir yang tepat untuk mengurangi masalah antrian kendaraan akibat kendaraan parkir pada badan jalan. Analisis finansial yang dilakukan juga menunjukan bahwa perencanaan lahan parkir ini layak untuk dilaksanakan.

\section{Kesimpulan}

Hasil survei volume kendaran parkir menunjukkan hasil volume maksimal sebagai berikut. Untuk kendaraan roda dua sebesar 1.472 kendaraan dengan akumulasi maksimal sebesar 439 kendaraan. Untuk kendaraan roda empat sebesar 221 kendaraan dengan akumulasi maksimal sebesar 84 kendaraan.

Untuk kendaraan roda dua sebanyak 650 petak parkir dengan kebutuhan petak parkir sebesar 439 petak, dan untuk kendaraan roda empat sebanyak 49 petak parkir dengan kebutuhan 84 petak parkir. Dengan begitu lahan parkir diperuntukkan hanya untuk kendaraan roda dua. Sementara parkir kendaraan roda empat ditempatkan pada badan jalan dengan posisi parkir satu sisi $45^{\circ}$.

Hasil analisis finansial lahan parkir sebagai berikut. Net Present Value (NPV) positif dengan suku bunga $0,37 \%$ sebesar Rp 68.850.595dan NPV negatif dengan suku bunga 0,56\% sebesar Rp (3.271.259) yang berarti investasi dinyatakan layak jika suku bunga diantara $0,37 \%-0,56 \%$. Untuk nilai Internal Rate Of Return (IRR) sebesar $0,55 \%$ yang berarti investasi dinyatakan layak. Untuk nilai Benefit Cost Ratio (BCR) sebesar 1,55 yang berarti investasi dinyatakan layak. Untuk 
Payback Periodnya, dinyatakan dalam grafik dan didapatkan titik Break Event Point (BEP) yang jatuh pada bulan ke 8 .

\section{Daftar Pustaka}

Direktorat Jendral Perhubungan Darat, 1998, Pedoman Perencanaan dan Pengoperasian Fasilitas Parkir, Direktorat Jendral Perhubungan Darat.

Giffari, F. R., 2017, Perencanaan Park And Ride Terminal Leuwi Panjang, Skirpsi, Surabaya: Fakultas Teknik Sipil dan Perencanaan Institut Teknologi Sepuluh Nopember.

Handayani, D., Ajeng, R., Purnomoasri, D., dan Legowo, S. J., 2020, Analisis Kelayakan Finansial Gedung Parkir Sepeda Motor, e-jurnal MATRIKS TEKNIK SIPIL, 1022-1028.

Kasuma, I. G., 2011, Analisis Kelayakan Finansial Rencana Pembangunan Gedung Parkir Bertingkat Di Pasar Lokitasari, Tesis untuk memperoleh Gelar Magister Program Magister, Program Studi Teknik Sipil Program Pascasarjana Universitas Udayana.

Kriswardhana, W., dan Wahyudi, I., 2017, Model Pengaruh Hambatan Samping Terhadap Nilai Kapasitas Jalan Dan Biaya Operasi Kendaraan Pada Ruas Jalan Jawa Kabupaten Jember, SeNaTS 2, (Bali, 8 Juli 2017).

Lisan, M. F., 2014, Studi Kelayakan Finansial Pembangunan Gedung Parkir Ponpes Amanatul Ummah Desa Kembang Belor Kecamatan Pacet Mojokerto, Metodologi Penelitian, 1(1), 30.

Marusenge, G. S., Timboeleng, J. A., dan Elisabeth, L., 2015, Pengaruh Hambatan Samping Terhadap Kinerja Pada Ruas Jalan Panjaitan (Kelenteng Ban Hing Kiong) Dengan Menggunakan Metode Mkji 1997, Jurnal Sipil Statik, 3(8), 571-582.

Pramesia, M., 2019, Perencanaan Kebutuhan Ruang Parkir RSUD Genteng, Skripsi, Jember: Fakultas Teknik Sipil Universitas Jember.

Peraturan Pemerintah Republik Indonesia Nomor 43 Tahun 1993. Prasarana Dan Lalu Lintas Jalan. Lembaran Negara Tahun 1992 Nomor 49.

Rauf, H., Sendow, T. K., dan Rumayar, A. L. E., 2015, Analisa Kinerja Lalu Lintas Akibat Besarnya Hambatan Samping Dengan Menggunakan Regresi Linier Berganda ( Studi Kasus Ruas Jalan Dalam Kota Pada Segmen Jalan Lumimuut ), Jurnal Sipil Statik, 3(10), 669-684.

Tataming, E. S., Sendow, T. K., Kaseke, O. H., \& Diantje, S., 2014, Analisis Besar Kontribusi Hambatan Samping Terhadap Kecepatan Dengan Menggunakan Metode Regresi Linear ( Studi Kasus: Ruas Jalan dalam Kota Segmen Ruas Jalan Sarapung ), Jurnal Sipil Statik, 2(1), 29-36. 